\title{
Influence of Endogenous Human Capital on China's Economic Growth
}

\section{Zhao Li}

Glorious Sun School of Business and Management (GSSBM), DongHua University, China.

Email:lizhao021@163.com

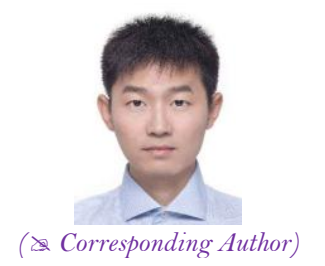

(D) Check for updates

\begin{abstract}
Based on the framework of endogenous economic growth, this paper took the education sector as a separate human capital production sector, and then an economic growth model with endogenous human capital accumulation is constructed, and a combination of theoretical derivation and simulation is used for the education investment behavior of the Chinese household sector, as well as the analysis of the efficiency of human capital accumulation. Based on above theoretical analysis, then to study the impact of educational investment on economic growth. The study found that the more the elasticity of education investment, the higher the efficiency of human capital accumulation, and the greater willingness of families to increase investment on education. Human capital accumulation is a key factor in determining the economic growth potential of a country or region, and education is the most important way for the accumulation of human capital. The investment in education is necessary for China under the condition of the economic growth rate slowing down.
\end{abstract}

Keywords: Investment, Time-lag effect, Human capital accumulation, Economic growth.

JEL Classification: E2 1, E22, H52.

\section{Introduction}

"Why are some countries richer than others?" Solow's seminal paper showed that capital accumulation could account for differences in output per capita. Further, Lucas (1988) found that human capital disparities were key factor for countries differences. The following researches (eg. (Aisen \& Veiga, 2013; Benos \& Zotou, 2014)) have estimated the impact of human capital on economic growth through cross-section analysis and concluded that differences in the average schooling of countries are related to different economic growth rates. The concept of human capital can be interpreted as the set of intangible resources embedded in the labor factor. Individuals with more education are more productive and innovative leading to the creation of new products and improving the productivity of factors (Goldin, 2016).

Although, human capital is key factor that affect the economic growth, how to measure and how the human capital accumulated are still controversial. The standard approach largely inspired by the work of Mincer (1974) takes estimates of the rate of return to schooling as building blocks to directly measure a country's stock of human capital. Implicitly, this method assumes that the marginal contribution to output of one additional year of schooling is equal to the Mincerian rate of return. One problem with this procedure is that it is not well suited to handle cross-country differences in the quality of human capital. The main ways of accumulating human capital are education and learn by doing (Becker, 2009) and in general there is a positive correlation between an individual's ability and their level of education. As a result, scholars often use the average level of education of employees as substitutes for human capital stock or human capital accumulation (Schündeln \& Playforth, 2014). Using the education output to directly measure the stock of human capital, it may ignore the process how human capital produce, namely it lacks an education sector.

Based on the above considerations, this paper firstly establishes a theoretical model that includes education sectors. The education sector generates human capital, and human capital as a factor of production enters the production sector, affecting the production of the national economy. Taking the duality of production function and cost function, the educational input (cost) is used as the explanatory variable of educational output (human capital). The investment in education has the time lag effect in the formation of human capital. That is, the current investment in education cannot be fully reflected in the stock of human capital in the current production field and therefore will not directly affect the output of the national economy in the current period, which is often ignored by mostly researches.

This paper consists of six parts. The first part is the introduction. The second part is literature review. The third part is the derivation of the theoretical model, including the education production function, cost function in 
the education sector, and the national economic production function in the production sector. The fourth part is calibration. The fifth part is conclusion.

\section{Literature Review}

At present, the main methods of measurement of human capital include "cost method", "income method" and "education index method". Among these methods, the education indicator method is relatively simple and easy to implement. The common education indexes are adult literacy rate, enrollment rate and average years of schooling (Laroche \& Merette, 2000). However, the education indicator method only focuses on the simple arithmetic mean, which is not enough to reflect the difference in the return rate of education among different groups of people. The essence of cost method is to calculate all the expenditures in the process of human capital formation (Kendrick, 1976). It is assumed that the higher the cost paid, the higher the accumulated human capital. Moreover, different from physical capital, human capital accumulation is a relatively long-term and complicated process. The time span of human capital accumulation determines that the cost method measures human capital requires long-term data support. It is difficult for China's current data to support detailed cost method research. Different from the cost method, the income method regards human capital accumulation as a long-term investment, and measures the current human capital stock with the present value of individual lifetime return (Jorgenson \& Fraumeni, 1992). However, the income method also has its defects. It is necessary to assume some important parameters, especially the income growth rate and the discount rate. For example, Li, Li, Qiu, Guo, and Tang (2014) used labor productivity growth as an approximation of the actual income growth rate to forecast future personal income, and use the OECD's human capital discount rate. Since the income method has assumed the economic growth rate advanced, using human capital to explain the economic growth of a country will fall into the logical trap of circular argumentation. However, at present the education indicator are most popular used in the researches because of its easily measurement.

The above methods are only the ways to measure the human capital stock, but about the process of how the human capital production is still hard to classify. Human capital accumulation is essential of the process to acquire knowledge and skills through education, experience and health care. Acquiring skills and knowledge is a means of capital formation by delaying consumption with the aim of increasing future income. Human capital improves the quality of labor, increasing its productivity (Bodman \& Le, 2013). However, in most of the literature on educationhuman capital as the driving force of economic growth, the input-output relationship of the education sector is often simplified: The education department with linear production technology mechanically converts inputs into human capital. Some scholars have modified the hypothesis of linear human capital production technology in the education sector and verified it using micro-level data. However, using macro-level data to empirically analysis the education sector's production process and its efficiency is rare. This paper introduces the education sector into the endogenous economic growth model to show the process of the human capital accumulation. Combined with the characteristics of China's education system, it analyzes the effects of education investment on human capital accumulation and further economic growth.

\section{Methodology}

\subsection{Household Sector}

The representative consumer maximizes his utility across time.

$$
\mathrm{U}\left(c_{t}\right)=\int_{0}^{\infty} e^{-\rho t} \frac{c_{t}^{1-\theta}}{1-\theta} \mathrm{dt}
$$

Where, $\theta$ the inverse of the elasticity of substitution, $\theta>1$ and $\rho$ the discount rate.

In period $t_{0}$, the initial endowment of the household is $k_{0}$ units of physical capital and $h_{0}$ units of human capital. Then each period, the household leases physical capital to the firm at a rent rate $r_{t}$ and provides the firm with $h_{t}$ units effective workforce at a wage rate of $w_{t}$. The household allocates total income between consumption, physical capital investment, and human capital investment. The corresponding budget constraints are:

$$
c_{t}+e_{t}+i_{t}=w_{t} \cdot h_{t}+r_{t} \cdot k_{t}
$$

The capital accumulation equation is set as follows:

$$
\dot{k_{\mathrm{t}}}=w_{t} \cdot h_{t}+r_{t} \cdot k_{t}-c_{t}-e_{t}-\delta_{k} k_{t}
$$

Here, $\delta_{K}$ is depreciation rate of physical capital.

\subsection{Production Function}

In this paper, begin with a basic model of economic growth in which aggregate output at date $t$ is determined by the size of the physical capital, human capital and the state of technology, then the production function will be set as:

$$
y_{t}=A \cdot k_{t}^{\alpha} \cdot h_{t}^{1-\alpha}
$$

Here, $Y_{\mathrm{t}}$ is final output, $A$ is a measure of technology, $k_{t}$ is total physical capital, $h_{\mathrm{t}}$ is human capital, $0<\alpha<$ 1 is output elasticity of physical capital.

In the complete competitive market conditions, the first-order conditions for maximizing the profit of a representative firm are:

$$
r_{t}=\alpha \cdot z_{t}^{\alpha-1}, w_{t}=(1-\alpha) \cdot z_{t}^{\alpha}
$$

Where, $z_{t}=k_{t} / h_{t}$, is the ratio of physical capital to effective labor. 


\subsection{Endogenous Human Capital}

ASSUMPTION 1: Education investment is an important means to improve the quality of human capital, and it is also an important process for the accumulation of human capital (Sehrawat \& Giri, 2017). Education can be divided into elementary education and higher education. Elementary education is compulsory education in some countries. At this stage, people receive general basic education, while higher education fosters scientific and technological progress in a country by cultivating high-tech talents. This in turn promotes productivity growth. Educational investment does not always positively co-relate to economic growth (Ahsana \& Haque, 2017). The misallocation of human capital structures caused by over-education will inhibit economic growth (Teixeira \& Queirós, 2016). Although human capital is a key factor in promoting economic growth, the structural unemployment caused by higher education misallocation makes the basic labor supply insufficient, which in turn hinders economic growth. Thus, the accumulation of human capital does not directly promote economic growth. The role of human capital depends on certain industry structure and the economic institutions. Besides, economic development level of a country determines the type of the dominant export sector and the type of major export products, which in turn leads to the demand for related talents. It promotes the demand for education. Among them, the growth of non-technology-intensive exports has inhibited the average number of years of education in the country, while the growth of technology-intensive exports has long-term role in promoting the country's education level (Blanchard \& Olney, 2017). For simplicity, assume that human capital has no depreciation. Then, the human capital accumulation function is as follow:

$$
\dot{h}_{t}=\mathrm{B} \cdot e_{t}^{\gamma} \cdot I^{v}
$$

Here, $\mathrm{B}$ is constant, $\gamma$ is elasticity of education investment, $v$ is elasticity of industrial structure.

\subsection{General Equilibrium and the Growth Path}

Objective function:

The constraint is:

$$
\max \int_{0}^{\infty} e^{-\rho t} \mathrm{U}\left(c_{t}\right) \mathrm{dt}
$$

$$
\dot{k_{\mathrm{t}}}=w_{t} \cdot h_{t}+r_{t} \cdot k_{t}-c_{t}-e_{t}-\delta_{k} k_{t}
$$

The Hamiltonian function for this problem is :

$$
\mathrm{H}=\frac{c_{t}^{1-\theta}}{1-\theta}+\lambda_{t}\left(w_{t} \cdot h_{t}+r_{t} \cdot k_{t}-c_{t}-e_{t}-\delta_{k} k_{t}\right)+\mu_{t} \mathrm{~B} \cdot e_{t}^{\gamma} \cdot I^{v}
$$

In the above formula, $\lambda_{t}$ is the shadow price of $k_{t}, \mu_{t}$ is the shadow price of $e_{t}$. Where, $k_{t}$ and $h_{t}$ are state variables, $\mathrm{c}_{\mathrm{t}}$ and $e_{t}$ are control variables.

According to the first order condition, then,

$$
\begin{gathered}
c_{t}^{-\theta}=\lambda_{t} \\
-\lambda_{t}+\mu_{t} \gamma \mathrm{B} \cdot e_{t}^{\gamma-1} \cdot I^{v}=0
\end{gathered}
$$

Then the Euler equation is,

$$
\begin{gathered}
\frac{\dot{\lambda}}{\lambda}=-r_{t}+\rho+\delta_{k} \\
\frac{\dot{\mu}}{\mu}=\rho-w_{t} \cdot \gamma \mathrm{B} \cdot e_{t}^{\gamma-1} \cdot I^{v}
\end{gathered}
$$

TVC

$$
\lim _{t \rightarrow \infty} e^{-\rho t} \cdot \lambda_{t} \cdot k_{t}=0
$$

Log-differentiating equations 10,11 and combining it with equations 13,14 produces consumption growth rate, and divide equations 8 both sides $k_{\mathrm{t}}$ produces physical capital growth rate :

$$
\begin{gathered}
\frac{\dot{c}}{c}=\frac{1}{\theta}\left(\alpha \cdot z_{t}^{\alpha-1}-\delta_{k}-\rho\right) \\
\frac{\dot{e}}{e}=\frac{1}{\gamma-1}\left((1-\alpha) \cdot z_{t}^{\alpha} \cdot \gamma \mathrm{B} \cdot e_{t}^{\gamma-1} \cdot I^{v}-\alpha z_{t}^{\alpha-1}+\delta_{k}\right) \\
\frac{\dot{k}}{k}=z_{t}^{\alpha-1}-\frac{c_{t}}{k_{t}}-\frac{e_{t}}{k_{t}}-\delta_{k}
\end{gathered}
$$

Here $z_{t}=k_{t} / h_{t}$, is the ratio of physical capital to effective labor, and define $\chi_{t}=c_{t} / e_{t}$. Equations. 1516 and 17 , fully characterize the dynamics of the economy. This system can be solved for its steady state, $\dot{c} / c=0 \dot{k} / k=$ $0, \dot{e} / e=0$, then we can get ratio of physical capital to effective labor, the per capital effective consumption and per capita effective education investment in equilibrium state: $Z^{*}, e^{*}$, and $\chi^{*}$ :

$$
\begin{gathered}
z^{*}=\left(\frac{\alpha}{\delta_{k}+\rho}\right)^{\frac{1}{1-\alpha}} \\
e^{*}=\left(\frac{\rho}{1-\alpha}\left(\frac{\delta_{k}+\rho}{\alpha}\right)^{\frac{\alpha}{1-\alpha}} \frac{1}{\gamma B I^{v}}\right)^{\frac{1}{\gamma-1}} \\
\chi^{*}=\frac{\rho}{1-\alpha} \frac{1}{\gamma}-\frac{\alpha}{\delta_{k}+\rho} \frac{\rho}{1-\alpha} \frac{\delta_{k}}{\gamma}-1
\end{gathered}
$$


PROPOSITION1: There exists a BGP along which the income shares of capital and labor are constant and strictly positive when factors are paid their marginal products, only when $\rho / \gamma(1-\alpha)>\alpha \rho \delta_{K} / \gamma\left(\delta_{K}+\rho\right)(1-\alpha)+1$.

From the Equation 19 we can know that the per capita effective capital in equilibrium state: $z^{*}$ is affected by the parameters fixed capital depreciation rate $\delta_{k}$ and time preference $\rho$ changes. When $\delta_{k}$ or $\rho$ increases, the per capita effective capital will decrease. The education investment $e^{*}$ is affected mainly by the elasticity of education investment $\gamma$. When $\gamma$ increases, the education investment will increase. The more the elasticity of education investment, the higher the efficiency of human capital accumulation, and the greater willingness of families to increase investment on education.

\section{Calibration}

The previous section analyzed the effects of household education investment on human capital accumulation and economic growth by constructing a theoretical model. However, there are many exogenous parameters in the model. Therefore, taking the China's data from 1997 to 2016 as a sample, the paper firstly obtained a reasonable value for the structural parameters of the model and then calibrated the model. Second, the calibration was used to analyze the impact of household education investment on human capital accumulation and economic growth.

\subsection{Parameters Sets}

\subsubsection{Utility Function Parameter Setting}

About intertemporal substitution elasticity, the results of foreign and domestic studies were widely divergent. Empirical analysis using total consumption data usually finds that cross-substitution elasticity $1 / \theta$ was close to zero, and a calibration model to match growth and fluctuation facts usually needed to set the value close or equal to $1 \mathrm{Gu}$, Yan, and Chen (2013) measured the inter-substitution elasticity of consumption of China's household consumption from 2000 to 2008 and found that the elasticity of intertemporal substitution in most years was around 0.3. With reference to relevant research at home and abroad, the benchmark intertemporal substitution elasticity value is set to 0.5 , namely the risk aversion coefficient $\theta$ is 2 .

\subsubsection{Firm Production Function Parameter Setting}

Estimated that the output elasticity of China's physical capital from 1952 to 2010 was 0.6576; Zhu and Feng (2014) calculated that the output elasticity of physical capital from 1997 to 2011 was 0.745 . Based on the above domestic research, we set the output elasticity of physical capital in the production function to 0.7. In addition, the technical parameter A of the production function is normalized to 1 .

\subsubsection{Physical Capital Depreciation Rate}

Most of the literature set the depreciation rate of physical capital $5 \%$ or $6 \%$. This paper calculates the average depreciation rate of fixed assets from 1997 to 2016 according to the relevant data according to the "China Statistical Yearbook", was $5.23 \%$, which is basically consistent with the general capital depreciation rate of the literature. Therefore, this paper sets the annual depreciation rate of physical capital to $5 \%$.

\subsubsection{Human Capital Output Elasticity}

About the output elasticity of human capital $\gamma$, many studies at home and abroad pointed out that there was an important relationship between the output elasticity of human capital and the return on education investment. Psacharopoulos and Patrinos (2004) found that every extra year of education leads to an increase in wages ranging from $8.4 \%$ to $13.2 \%$, with an average of $10.2 \%$. Feng, Zhu, and Yang (2012) found that for every one year increase in the average number of years of education for Chinese employed personnel from 1998 to 2010, the average wage level will increase by $11 \%$. Therefore, the paper set the rate of return on education investment to $10 \%$, so that the calculated output elasticity of human capital was 0.8. In order to test the robustness of the value, the sensitivity test will be performed later. All the parameters set are shown in the Table 1.

Table-1. Model parameters and variable values.

\begin{tabular}{l|c|c}
\hline Parameter & Symbol & Value \\
\hline Intertemporal substitution elasticity & $1 / \theta$ & 2 \\
\hline Total factor productivity & $A$ & 1 \\
\hline Physical capital output elasticity & $\alpha$ & 0.7 \\
\hline Physical capital depreciation rate & $\delta_{k}$ & 0.05 \\
\hline Human capital output elasticity & $\gamma$ & 0.8 \\
\hline
\end{tabular}

\subsection{Calibration Results and Analysis}

Based on the model parameters set, then using the number simulation method, the calibration results are as show in the Table 2. Time preference rate $\rho$ is 0.9905 and technical level of human capital production function are 0.610. According to the parameters, this paper further studied the effect of household education expenditure on output growth rate through numerical simulation. As is show in Figure 1. 
Table-2. Calibration Results.

\begin{tabular}{l|c|c}
\hline Parameter & Symbol & Value \\
\hline Time preference rate & $\rho$ & 0.9905 \\
\hline Technical level parameters of human capital production function & $B$ & 0.610 \\
\hline
\end{tabular}

Figure 1 shows that the household education investment is positively related with economic growth. Household education investment belongs to productive public expenditure and helps to increase the marginal output of physical capital. Therefore, household are willing to save more and promote the accumulation of physical capital. The increase in household education investment has positive effects on both human capital accumulation and physical capital accumulation, and promotes economic growth.

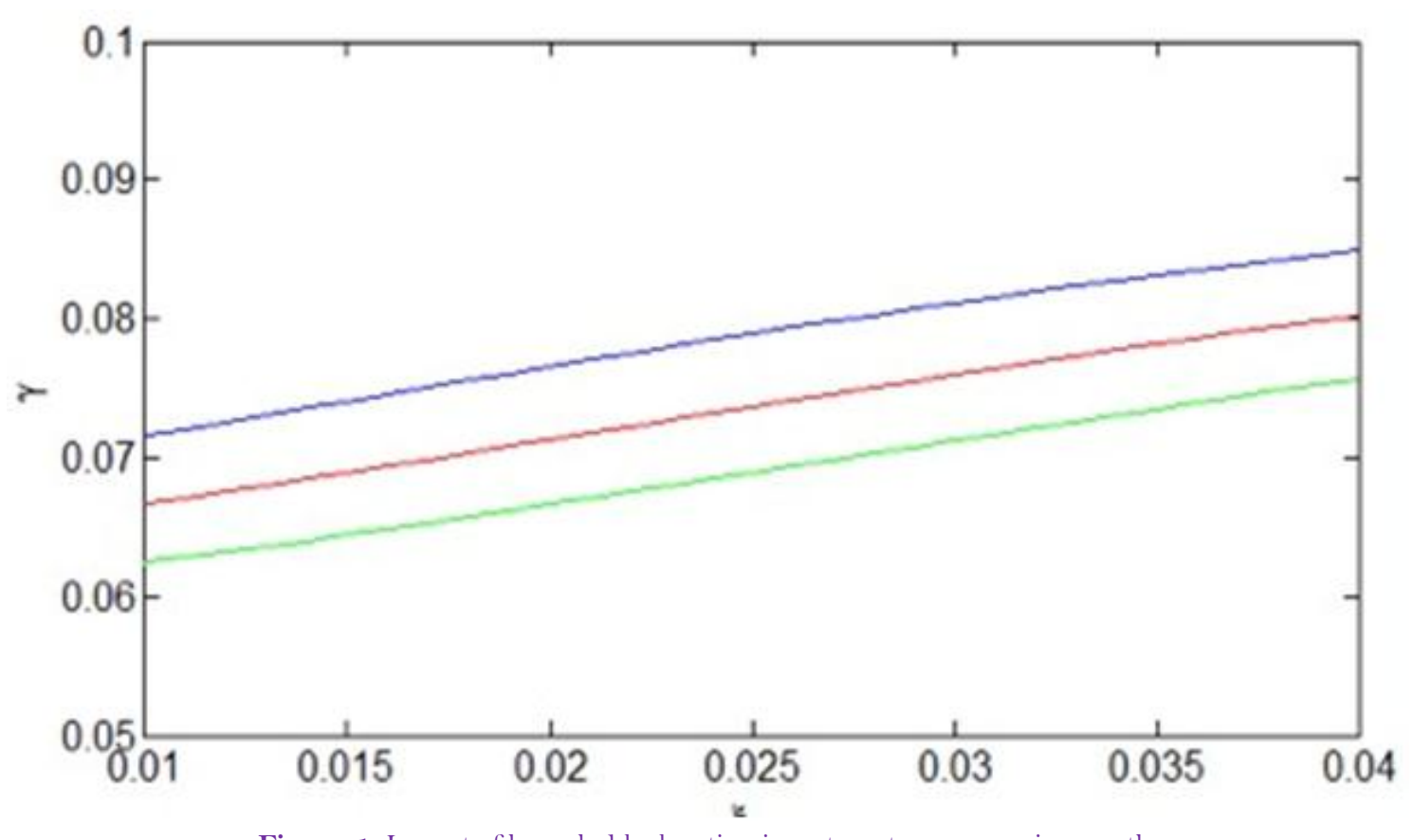

Figure-1. Impact of household education investment on economic growth.

\subsection{Sensitivity Test}

Examining whether the parameters preset changes will significantly affect the simulation results, we analyze the effect of the sensitivity of the structural parameters on each endogenous variable in the model to check if the simulation results are robust. As is shown in the Table 3, firstly, firm sector, the lower value, benchmark value, and upper value of the output elasticity of physical capital are taken as 0.6, 0.7, and 0.8, respectively. Secondly, human capital production, the output elasticity of the human capital, lower value, the benchmark value and the upper value are $0.6,0.8$ and 0.90 respectively.

Table-3. Impact of model parameters sensitivity analysis on economic growth.

\begin{tabular}{|c|c|c|c|c|c|c|c|c|}
\hline \multirow{3}{*}{$\begin{array}{l}\text { Rarameters } \\
\text { Endogenous } \\
\text { variables }\end{array}$} & \multicolumn{4}{|c|}{ Output elasticity of physical capital $\alpha$} & \multicolumn{4}{|c|}{$\begin{array}{c}\text { Output elasticity of education investment } \\
\gamma\end{array}$} \\
\hline & Lower & Benchmark & Upper & \multirow{2}{*}{ Trend } & Lower & Benchmark & Upper & \multirow{2}{*}{ Trend } \\
\hline & 0.60 & 0.70 & 0.80 & & 0.60 & 0.8 & 0.9 & \\
\hline $\mathrm{e} / \mathrm{y}$ & 0.021 & 0.019 & 0.017 & $\begin{array}{c}\text { Monotonous } \\
\text { decline }\end{array}$ & 0.021 & 0.019 & 0.018 & $\begin{array}{c}\text { Monotonous } \\
\text { decline }\end{array}$ \\
\hline $\mathrm{k} / \mathrm{y}$ & 1.813 & 2.100 & 2.437 & Monotonous rise & 2.246 & 2.100 & 1.898 & $\begin{array}{c}\text { Monotonous } \\
\text { decline }\end{array}$ \\
\hline $\mathrm{h} / \mathrm{y}$ & 0.250 & 0.177 & 0.125 & $\begin{array}{l}\text { Monotonous } \\
\text { decline }\end{array}$ & 0.224 & 0.177 & 0.151 & $\begin{array}{c}\text { Monotonous } \\
\text { decline }\end{array}$ \\
\hline$\Delta \mathrm{y} / \mathrm{y}$ & 0.082 & 0.075 & 0.069 & $\begin{array}{l}\text { Monotonous } \\
\text { decline }\end{array}$ & 0.081 & 0.075 & 0.072 & $\begin{array}{l}\text { Monotonous } \\
\text { decline }\end{array}$ \\
\hline
\end{tabular}

From above sensitivity analysis, it can be found that: The Chinese economic growth numerical simulation solution based on the accumulation of human capital and physical capital is robust; When the model parameters change near the benchmark value, the Chinese economic growth path will not appear obvious change.

\section{Conclusion}

Accumulation of human capital is a key factor in determining the economic growth potential of a country or region, and education is the most important way to accumulate human capital. Empirical researches of the economic growth model driven by the accumulation of human capital mainly tends to verify the relationship between education and economic growth. However, the production process (input-output relationship) in the education sector is a black box. The impact of education on the accumulation of human capital and the efficiency of education have not been given due attention. Based on the framework of endogenous economic growth, this paper took the education sector as a separate human capital production sector, and then an economic growth model with endogenous human capital accumulation is constructed, and a combination of theoretical derivation and simulation is used for the education investment behavior of the Chinese household sector, as well as the analysis of the efficiency of human capital accumulation. Based on above theoretical analysis, then to study the impact of 
educational investment on economic growth. The study found that the more the elasticity of education investment, the higher the efficiency of human capital accumulation, and the greater willingness of families to increase investment on education. Human capital accumulation is a key factor in determining the economic growth potential of a country or region, and education is the most important way for the accumulation of human capital. Under the new normal, in order to achieve a change in the mode of economic growth, education investment should be increased.

\section{References}

Ahsana, H., \& Haque, M. E. (2017). Threeshold effects of human capital: Schooling and economic growth. Economic Letters, 156(4), 48-52.

Aisen, A., \& Veiga, F. J. (2013). How does political instability affect economic growth? European Journal of Political Economy, 29, 151167.Available at: https://doi.org/10.1016/j.ejpoleco.2012.11.001.

Becker, G. (2009). Human capital: A theoretical and empirical analysis, with special reference to education: University of Chicago Press.

Benos, N., \& Zotou, S. (2014). Education and economic growth: A meta-regression analysis. World Development, 64, 669-689.Available at: https://doi.org/10.1016/j.worlddev.2014.06.034.

Blanchard, E. J., \& Olney, W. W. (2017). Globalization and human capital investment: Export composition drives educational attainment. Journal of International Economics, 106, 165-183.Available at: https://doi.org/10.1016/j.jinteco.2017.03.004.

Bodman, P., \& Le, T. (2013). Assessing the roles that absorptive capacity and economic distance play in the foreign direct investmentproductivity growth nexus. Applied Economics, 45(8), 1027-1039.Available at: https://doi.org/10.1080/00036846.2011.613789.

Feng, X., Zhu, Y.-Y., \& Yang, Q. (2012). Study on China's national production function based on human capital distribution variance. Chines Economic Quarterly, 1 1(2), 559-594.

Glewwe, P. and Kremer, M. (2006) Schools, Teachers, and Education Outcomes in Developing Countries. In: Hanushek, E.A. and Welch, F., Eds., Handbook of the Economics of Education, Vol. 2, North Holland Publishing Co, Amsterdam, 945-1017.

Goldin, C. (2016). Human capital. In: Diebolt, C., Haupert, M. (Eds.), Handbook of Cliometrics (pp. 55-86). Berlin, Heidelberg: SpringerVerlag.

Gomes, F. A. R., \& Paz, L. S. (2013). Estimating the elasticity of intertemporal substitution: Is the aggregate financial return free from the weak instrument problem? Journal of Macroeconomics, 36, 63-75.Available at: https://doi.org/10.1016/j.jmacro.2013.01.005.

Gu, L., Yan, H., \& Chen, B. (2013). Recursive statistical estimation of the annual replacing flexibility of residents' consumption in China. Economic Statistics Quarterly, 99(1), 95-100.

Jorgenson, D. W., \& Fraumeni, B. M. (1992). Investment in education and US economic growth. The Scandinavian Journal of Economics, 94, $51-70$.

Kendrick, J. W. (1976). The formation and stocks of total capital. In The Formation and Stocks of Total Capital (pp. 28-0). NBER.

Laroche, M., \& Merette, M. (2000). Measuring human capital in Canada: Ministry of Finance of Canada.

Li, H.-Z., Li, B., Qiu, Y.-F., Guo, D.-Z., \& Tang, T. (2014). China's human capital measurement: Method, results and applications. Journal of Central University of Finance \& Economics(5), 11.

Lucas, J. R. E. (1988). On the mechanics of economic development. Journal of Monetary Economics, 22(1), 3-42.

Mincer, J. A. (1974). Schooling, experience, and earnings. New York: Columbia University Press.

Psacharopoulos, G., \& Patrinos, H. A. (2004). Returns to investment in education: A further update. Education Economics, 12(2), 111134.Available at: https://doi.org/10.1080/0964529042000239140.

Schündeln, M., \& Playforth, J. (2014). Private versus social returns to human capital: Education and economic growth in India. European Economic Review, 66, 266-283.Available at: https://doi.org/10.1016/j.euroecorev.2013.08.011.

Sehrawat, M., \& Giri, A. K. (2017). An empirical relationship between financial development indicators and human capital in some selected Asian countries. International Journal of Social Economics, 44(3), 337-349.

Teixeira, A. A., \& Queirós, A. S. (2016). Economic growth, human capital and structural change: A dynamic panel data analysis. Research Policy, 45(8), 1636-1648.Available at: https://doi.org/10.1016/j.respol.2016.04.006.

Zhu, Y. Y., \& Feng, X. (2014). China's national production function since 1997: A reinvestigation. London: London Metropolitan Business School.

Citation | Zhao Li (2020). Influence of Endogenous Human Capital

on China's Economic Growth. Asian Business Research Journal, 5:

13-18.

History:

Received: 26 June 2020

Revised: 29 July 2020

Accepted: 12 August 2020

Published: 2 September 2020

Licensed: This work is licensed under a Creative Commons

Licensed: This work is licen
Attribution 3.0 License (oc) EY

Publisher: Eastern Centre of Science and Education
Acknowledgement: This study contributes in the existing literature that this paper tried to construct an Endogenous Human Capital on China's Economic Growth.

Funding: This study received no specific financial support.

Competing Interests: The author declares that there are no conflicts of interests regarding the publication of this paper.

Transparency: The author confirms that the manuscript is an honest, accurate, and transparent account of the study was reported; that no vital features of the study have been omitted; and that any discrepancies from the features of the study have been omit
study as planned have been explained.

Ethical: This study follows all ethical practices during writing.

Eastern Centre of Science and Education is not responsible or answerable for any loss, damage or liability, etc. caused in relation to/arising out of the use of the content. Any queries should be directed to the corresponding author of the article. 